\title{
Sternal abscess overlying giant aortic pseudoaneurysm developed after Bentall procedure
}

\author{
Bentall prosedürü sonrası gelişmiş dev aortik pseudoanevrizma üzerine oturmuş \\ sternal apse
}

Murat Tavlasoglu*, Adem Güler* ${ }^{* *}$ Mehmet Ali Şahin ${ }^{* *}$, Mustafa Kurkluoglu* ${ }^{* *}$ Faruk Cingöz ${ }^{* *}$, Mehmet Arslan**

* Diyarbakır Asker Hastanesi, Kalp Damar Cerrahisi Kliniği, Diyarbakır

** GATA Kalp ve Damar Cerrahisi Kliniği, Ankara

\begin{abstract}
Aortic pseudoaneurysms are one of the most important complications to be encountered in cardiac surgery. Recently, the aortic pseudoaneurysms have been diagnosed by contrast enhanced computerized tomography. It has high specificity and sensitivity rates. Late postoperative sternal abscesses are rarely seen after open heart surgery. Thorax computerized tomography scan revealed abscess extending from subcutaneous tissue to the medullar component of sternum, overlying retrosternal giant aortic pseudoaneurysms. This article presents the case of a patient, who had undergone Bentall procedure three years ago due to type I aortic dissection and later presented in our cardiovascular surgery department with a sternal mass.
\end{abstract}

Pam Med J 2013;6(1):33-36

Key words: Abscess; sternal wound infection; aortic pseudoaneurysm

\section{Özet}

Aortic pseudoanevrizmalar kalp cerrahisinde karşılaşılabilecek en önemli komplikasyonlardan biridir. Son zamanlarda aortic pseudoanevrizmalara kontrastlı bilgisayarlı tomografi ile tanı konmaktadır. Bu test oldukça yüksek özgüllük ve hassasiyet değerlerine sahiptir. Geç dönem sternal apseler açık kalp cerrahisinden sonra nadiren gözlenmektedirler. Bilgisayarlı toraks tomografisinde subkutanöz dokudan başlayıp sternum medullasına kadar uzanan absenin aortik retrosternal dev bir pseudoanevrizma üzerine oturduğu saptandı. Bu makalede; üç yıl önce tip I aortic diseksiyon nedeni ile Bentall ameliyatı olan ve daha sonra sternal kitle yakınmasıyla kalp damar cerrahisi kliniğimize müracaat eden hasta sunulmaktadır.

Pam Tıp Derg 2013;6(1):33-36

Anahtar sözcükler: Apse; sternal yara enfeksiyonu; aortik pseudoanevrizma

\section{Introduction}

Aortic valve replacement (mechanical valve, bioprosthesis or homograft) is recommended as a standard surgical procedure for most patients with symptomatic aortic valve disease [1]. The causes of the pseudoaneurysms of the ascending aorta in the early clinical era may usually be associated with endocarditis of the aortic prosthesis. With the increase in open heart surgery procedures, postoperative pseudoaneurysm of the ascending aorta has become more frequent. Aortic pseudoaneurysms are one of the most important complications to be encountered in cardiac surgery. Recently, the aortic pseudoaneurysms have been diagnosed by contrast enhanced computerized tomography. It has high specificity and sensitivity rates. However Aortic angiography remains the gold standard in the determination of the site, and severity of vascular injury for definitive surgical intervention [2]. Additionally, late postoperative sternal abscesses are rarely seen after open heart surgery. In this article we present a case, having sternal cold abscess overlying giant aortic pseudoaneurysm.

Murat Tavlasoglu

Yazışma Adresi: Diyarbakır Asker Hastanesi, Kalp damar Cerrahisi Kliniği, Diyarbakır

e-mail: mrttvls@gmail.com

Gönderilme tarihi: 04.08.2012

Kabul tarihi: 11.09.2012 


\section{Case Report}

A 62-year-old male patient who had a Bentall procedure three years ago due to type I aortic dissection was presented at our cardiovascular surgery department with a sternal mass. The patient had low grade fever with evening rise. In addition, anorexia was present for the last 3 months. In the clinical examination, a motionless, non-fluctuant, pulsatile, presternal swelling with a size of $4 \times 5 \mathrm{~cm}$ was found at the level of manubriosternal junction. However, there wasn't tenderness over spine and paraspinal muscles. The motion range of spine was in normal limits. Lymphadenopathy was not observed. In laboratory findings, erythrocyte sedimentation rate was $70 \mathrm{~mm} /$ hour and C-reactive protein test was positive. The chest radiograph was normal. Thorax CT scan revealed abscess extending from subcutaneous tissue to the medullar component of sternum, overlying a retrosternal giant aortic pseudoaneurysm that was extending from aortic root to the origin of right subclavian artery (Figure 1). Fine needle soft tissue abscess aspiration was performed prior to operation. The culture results were inconclusive. Cardiopulmonary bypass was achieved via femoral artery and vein. The sternal abscess was drained. The infected tissue was surrounded with granulation tissue and the composition was a brownish discharge extending to the inner table of the sternum (Figure 2A). The granulation tissue was curetted. Next, when the core temperature was at $18{ }^{\circ} \mathrm{C}$, the manubrium and the distal part of the sternum were divided by using oscillating saw (Figure 2B).

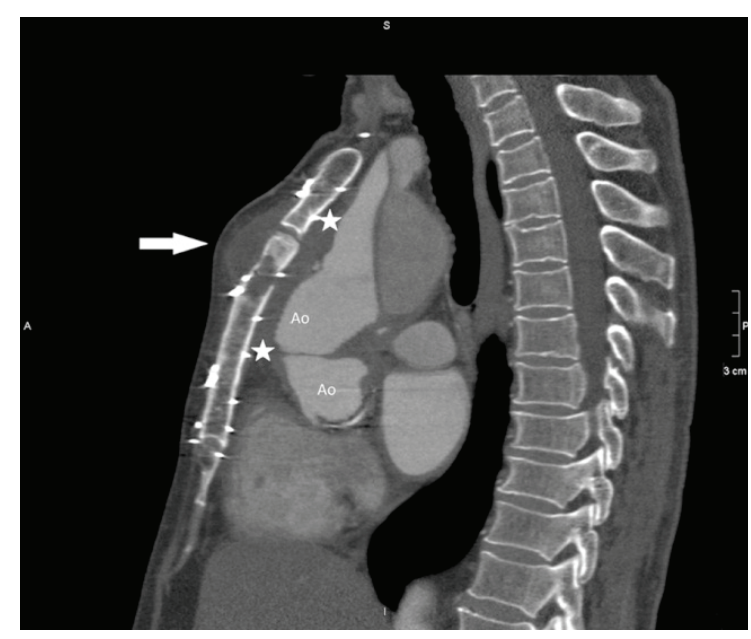

Figure 1. Sagittal reformatted CT demonstrates the abscess (arrow) and pseudoaneurysm (between two asterisks) (Ao: Aorta).
An intraoperative photograph demonstrates two pouches of abscess which were communicated to the subcutaneous tissue with a pore (Figure 2C). The graft and the surrounding tissue were examined for any sign of infection and no sign was observed. Total circulatory arrest was instituted at $18^{\circ} \mathrm{C}$, and the sack of the pseudoaneurysm was opened and aortotomy was performed in ascending aortic graft. Cold blood cardioplegia was delivered directly via cannulation of the coronary ostiums. Aortic root was examined, and communication between mechanical conduit and the aneurysmal sack could not be found at the level of aortic root. However, the hole was found at the distal anastomosis site which was between native aorta and synthetic graft communicating true lumen and pseudoaneurysm (Figure 2D). Three interrupted plegeted sutures were used externally to close the communication. After isolating the ascending aortic graft, cross clamping was performed. The total circulatory arrest time was fifteen minutes. The aortotomy was closed, and hot-shot cardioplegia was administered in an ante-grade fashion. After rewarming; the patient was decannulated as usual.

The tissue cultures were found clean, and Polymerase chain reaction was also negative for Mycobacterium tuberculosis complex. However, the abscess was clinically diagnosed as a cold abscess; therefore, the 4-antituberculous regimen (rifampin $600 \mathrm{mg} /$ day, pyrazinamide $2000 \mathrm{mg} / \mathrm{day}$, ethambutol $1600 \mathrm{mg} / \mathrm{day}$ and isoniazide $300 \mathrm{mg} / \mathrm{day}$ ) was started empirically and continued six months after operation. Aneight-week negative-pressure therapy using a vacuum pump dressing was achieved [3, 4]. Serous discharge from the sternum disappeared at the postoperative $8^{\text {th }}$ week. Outcome was satisfactory and no further surgery was needed up to two years during clinical follow-up after discharge.

\section{Discussion}

Rupture of the aortic pseudoaneurysm is a life-threating clinical disorder which may require urgent intervention. The pseudoaneurysm which was fusiform-shaped covered the ascending aorta circumferentially. Initially, it was supposed that the presternal mass was the continuation of the pseudoaneurysm; however, CT scan demonstrated that the mass was not associated with the pseudoaneurysm. The posterior lamina of the abscess was intact in CT scan. The infection was diagnosed as atypical mycobacterial sternal osteomyelitis infection 

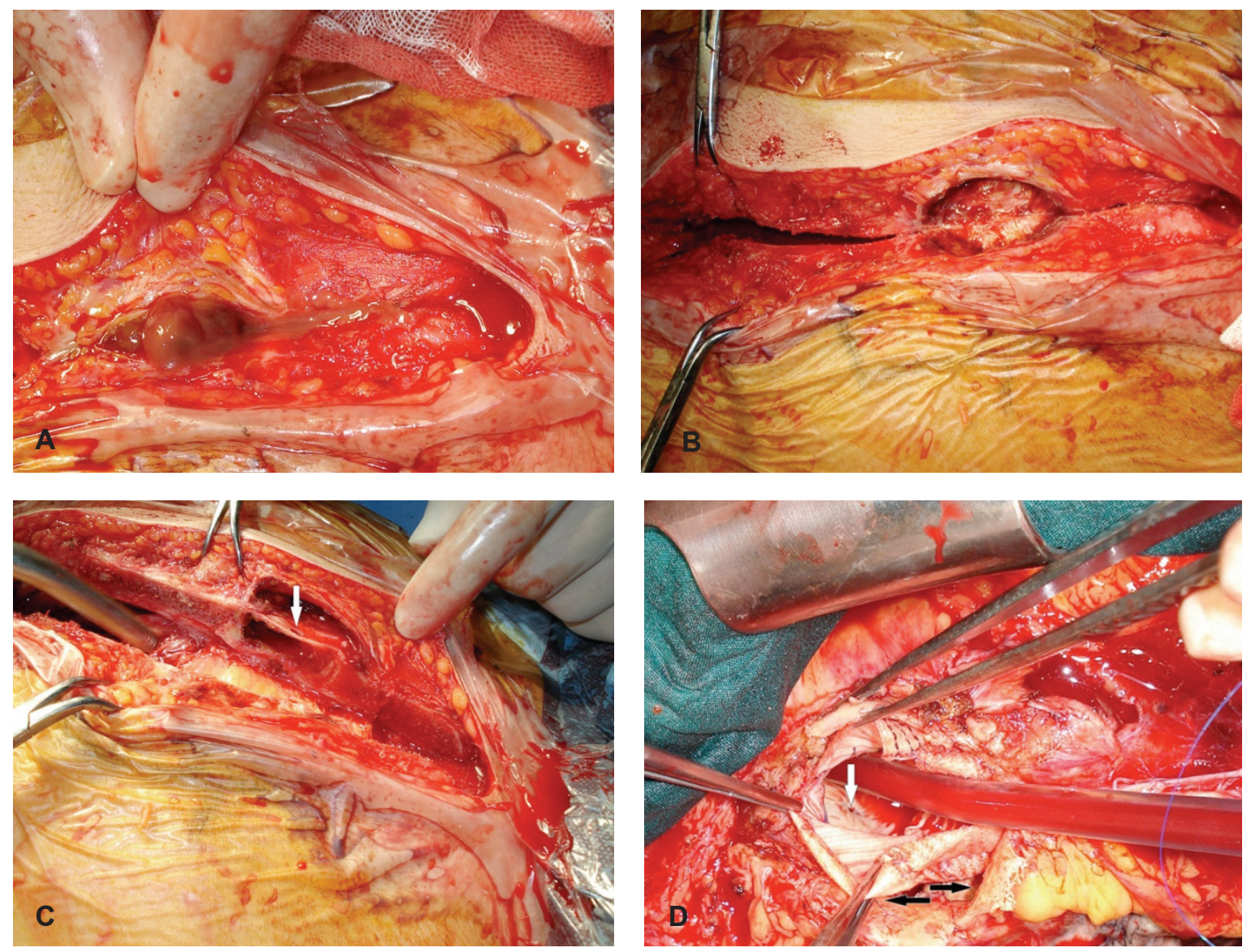

Figure 2. Intraoperative views show the drainage of the brownish abscess material (A), and the manubrium and the distal part of the sternum with drained pouch (B). Intraoperative photographs represent two pouches of abscess communicated with a pore (arrow, C), and the hole (white arrow, D), and pseudoaneurysmal sac covering synthetic graft (black arrows, D).

since the abscess did not show such usual signs as heat, redness, and painful palpation in clinical examination. In addition, it did not isolate any microorganism and Polymerase chain reaction was also negative for Mycobacterium tuberculosis complex.

A major surgical challenge is to choose the appropriate approach that enables safe entry into the chest when a pseudoaneurysm has become closer to the posterior lamina of the sternum. In our case, it was also closer to the posterior lamina. Hence, cardiopulmonary bypass was achieved via femoral artery and vein. Next, while cooling the patient for total circulatory arrest at $18{ }^{\circ} \mathrm{C}$, the abscess was drained and curetted. Then the surgical field was cleared again with $10 \%$ povidone - iodine solution and the surgical materials were replaced with the new sterile ones due to risk of graft infection before entering the anterior mediastinum. The sternal steel wires weren't removed completely; only the front parts of the steel wires were cut and removed completely just before entering the chest. This maneuver prevented us from entering into the aneurysmal sac accidentally during division of the sternum with oscillating saw.

Fortunately, when the anterior mediastinum was entered, the pseudoaneurysm wasn't torn. If the pseudoaneurysm had been torn, the total circulatory arrest would have been instituted to control the abundant bleeding in a few minutes by cross clamping the arcus aorta just distal to the right subclavian artery. In this case, the possible ventricular fibrillation was not observed at $18^{\circ} \mathrm{C}$ of core temperature before entering the anterior mediastinum. If it had been observed, the short intervals of ventricular fibrillation might have been well-tolerated by the heart without cardiac injury.

Postoperative pseudoaneurysms of the ascending aorta usually occur at sites of aortic wall disruption. Sullivan et al [5] reported 31 patients who developed pseudoaneurysm of the ascending aorta following cardiac 
surgery. Among the patients the most possible pseudoaneurysms sites were aortic cannulation site, aortotomy line, aortic valvulotomy site, CABG suture line, and needle puncture sites. In our case, the pseudoaneurysms entrance was detected at the distal anastomosis line.

In conclusion, atypical mycobacterial infections of sternum may have characteristics resembling to tuberculotic "cold abscess." Specialized laboratory testing is necessary since routine cultures are reported as negative, and surgical intervention may be required.

Moreover, in cases with giant pseudoaneurysms of the ascending aorta, sternal entries are the real challenging issues. Careful preoperative planning is necessary for safe entry. Methods for preventing blood loss and preservation of cerebral perfusion has great importance. The decision to institute cardiopulmonary bypass via axillary or femoral vessels should depend on the nature of each case.

Conflict of interest: The authors declared no conflict of interest.

\section{References}

1. Kirbaş A, Tanrıkulu N, Us M, Işık Ö. Aortopulmonary Fistula After the Native Aortic Valve Endocarditis. Journal of Clinical and Analytical Medicine DOI: 10.4328/JCAM.944.

2. Chen SY, Chang H, Lee SC, Hsu HH, Tzao C. Traumatic pseudoaneurysm from the aorta to the left common carotid artery presenting as widened mediastinum. Saudi Med J 2006; 27:1591-1593

3. Ford SJ, Rathinam S, King JE, Vaughan R. Tuberculous osteomyelitis of the sternum: successful management with debridement and vacuum assisted closure. Eur J Cardiothorac Surg 2005; 28:645-647

4. Gustafsson RI, Sjogren J, Ingemansson R. Deep sternal wound infection: a sternal-sparing technique with vacuum-assisted closure therapy. Ann Thorac Surg 2003; 76:2048-2053

5. Sullivan KL, Steiner RM. Smullens SN, Griska L, Meister SG. Pseudoaneurysm of the ascending aorta following cardiac surgery. Chest 1988; 93:138-143 